\title{
Building Quantities Explained
}


By the same author:

Civil Engineering Quantities

Civil Engineering Specification

Municipal Engineering Practice

Planned Expansion of Country Towns 


\title{
Building Quantities
}

\author{
Explained
}

\section{IVOR H. SEELEY}

B.SC., M.A., F.R.I.C.S., C.ENG., F.I.MUN.E., F.I.Q.S.

Chartered Quantity Surveyor

Principal Lecturer in Quantity Surveying

Nottingham Regional College of Technology

\section{S.I. Edition}

Macmillan Education 
(C) Ivor H. Seeley, 1969

First published 1965

Reprinted 1966

SI edition 1969

Reprinted 1970

Published by

MACMILLAN AND CO LTD

London and Basingstoke

Associated companies in New York, Melbourne

Toronto, Johannesburg and Madras

ISBN 978-0-333-12269-3 ISBN 978-1-349-01124-7 (eBook)

DOI 10.1007/978-1-349-01124-7 


\section{Preface to the Metric Edition}

THE PRIMARY AIM of this book, as was that of the first edition (1965), is to meet the needs of students preparing for intermediate examinations in quantities set by the City and Guilds of London Institute and by the various building and surveying bodies, or for degrees or Higher National or college diplomas or certificates in quantity surveying, building or construction.

This book is concerned with the measurement of relatively simple building work in accordance with the principles laid down in the Standard Method of Measurement of Building Works (metric edition) and contains many worked examples, accompanied by explanatory notes, covering all the basic building trades. It aims at simply explaining and illustrating the process of measuring building work and of clarifying the basic principles contained in the Standard Method, for the benefit of quantity surveying and building students.

The proposed change to metric has created tremendous problems for the construction industry, not least in having to rethink all measurements and weights in S.I. units. There is little doubt that many advantages will accrue from the resultant simplification of the measurement process and the expected rationalisation and standardisation of building products which will flow from the change, and finally we shall secure the benefits of much overdue dimensional co-ordination.

A programme of change has been formulated by the British Standards Institution whereby the bulk of the change will be completed by the end of 1971, but most examining bodies connected with the construction industry have decided to set their 1970 examination papers in metric terms. With the needs of these students in mind I have proceeded, as soon as was practicable, with the preparation of a fully metricated edition, although faced with many problems such as determining the method of: notating drawings in metric and the probable metric dimensions of a whole host of building components. At the time of going to press final decisions still had not been made on a number of issues involved, but I have (in consultation with B.S.I. and the manufacturers' organisations) determined feasible metricated values, in order that all descriptions can be expressed in metric terms. It has in a few instances necessitated making assumptions which may subsequently be proved wrong, and the initial metric dimensions of some components may later be changed to dimensionally co-ordinated sizes. For instance, I have described $11 \mathrm{in}$. hollow walls as $275 \mathrm{~mm}, 9 \mathrm{in}$. walls as $225 \mathrm{~mm}$ and $4 \frac{1}{2}$ in. walls as $110 \mathrm{~mm}$ and it is possible that they may subsequently be referred to as 255,215 and $102.5 \mathrm{~mm}$ walls respectively. This procedure is in line with B.S.I. recommendations whereby all 
concerned are advised to learn to think metric and not merely to adopt a two-stage process of visualising objects in imperial terms and then converting these values to metric terms.

Hence the equivalent imperial values have not been added in the examples in this book. Students wishing to familiarise themselves with relative values of metric and imperial measure in the early stages may find the metric conversion table in Appendix III to be helpful. This is an analogue conversion table using the nearest, neatest 'rounded-off' equivalent values.

Furthermore, a metric edition of B.S. 1192 relating to architectural and building drawing practice had not been isssued when the drawings were being prepared and, in consultation with B.S.I., it was decided to show all dimensions in metres with a decimal marker, while all other sets of figures represent millimetres. This procedure eliminates the need for the use of the ' $\mathrm{m}$ ' and ' $\mathrm{mm}$ ' symbols for dimensions on drawings.

Chapter XVI has been enlarged considerably to cover 'cut and shuffle' and the use of computers in greater detail and to permit the inclusion of information on standard phraseology and operational bills. Finally an entirely new chapter has been added to bring out the fundamental differences of approach in the measurement of small dwellings using the Code.

Nottingham

I. H. SEELEY

Autumn 1968 


\section{Acknowledgements}

THE AUTHOR expresses his thanks to the Standing Joint Committee for the Standard Method of Measurement of Building Works, for valuable assistance and for kind permission to quote from the Standard Method, and to Norman Wheatley, Honorary Secretary to the Standing Joint Committee, for supplying a copy of the draft metric edition and subsequently a proof of the final version, to help with the work of revision.

Philip Dunstone gave valuable advice on metric problems and the British Standards Institution through $R$. Harrison, secretary to metric panel $\mathrm{B} /-/ 9$, co-operated to the full in resolving difficulties stemming from the change to metric.

Grateful thanks are also due to Ronald Sears for his outstanding work in the preparation of drawings, figures and handwritten dimension sheets, which has added immeasurably to the value and quality of the book. Once again much kindly help and earnest consideration has been received from T. E. Blackall of the publishers throughout the production of the book.

Kind permission has been given by the Ellis School of Architecture, Surveying and Building, of London and Worcester, to incorporate some material which the author previously prepared for the School. I also value most highly the helpful suggestions made by my own colleagues at the Nottingham Regional College of Technology.

Lastly, I cannot express too highly my appreciation of the large measure of patience, forbearance and understanding which has been displayed continually by my own family, and without which this work could never have reached fruition.

Nottingham

I. H. SEELEY

Autumn 1968

\section{Abbreviations}

Will be found listed in Appendix I. 


\section{Contents}

Preface

Acknowledgements

Contents

Table of Figures

Table of Examples

I. GENERAL INTRODUCTION

Historical Background of Quantity Surveying - Purposes of Bill of Quantities - Processes used in Quantity Surveying Work Standard Method of Measurement of Building Works - Other Functions of the Quantity Surveyor - Modern Quantity Surveying Techniques : Methods of Preparation of Bills of Quantities; Forms of Bills of Quantities.

II. GENERAL PRINCIPLES OF 'TAKING-OFF'

General Rules - Dimension Paper - Entering Dimensions: Spacing of Items; 'Waste'; Order of Dimensions; Timesing; Abbreviations; Grouping of Dimensions; Deductions - Measurement of Irregular Figures - Alterations to Dimensions - Figured Dimensions Numbering and Titles of Dimension Sheets - Order of 'Taking-off'Adjustment of Openings and Voids - Descriptions - 'Extra Over' Items - 'Deemed to be Included' Items - Accuracy in Dimensions Use of Schedules - Query Sheets - Preambles - Prime Cost Items Provisional Sums - Protection Clauses.

III. USE OF MENSURATION IN QUANTITIES

Introduction - Girth of Buildings: Rectangular Buildings; Buildings of Irregular Outline - Measurement of Areas: Irregular Areas; Trapezoids; Segments; Bellmouths - Measurement of Earthwork: Sloping Site Excavation; Cuttings and Embankments - Measurement of Pitched Roofs: Lengths of Rafters; Lengths of Hips and Valleys; Roof Coverings.

IV. MEASUREMENT OF EXCAVATION AND FOUNDATIONS

Preliminary Investigations - Excavating Vegetable Soil; Excavation to Reduce Levels - Excavation for Foundation Trenches Disposal of Excavated Material - Levelling and Compacting Trench Bottoms - Basement Excavation - Planking and Strutting - Concrete in Foundations - Other Sub-Structural Work: Brickwork; Facework; Damp-proof Courses - Worked Examples. 
V. MEASUREMENT OF BRICKWORK, FACEWORK AND BLOCKWORK

Measurement of Brickwork: Measurement Generally; External Walls; Internal Walls; Chimney Breasts and Stacks - Measurement of Incidental Works: Damp-proof Courses; Rough Cutting; Eaves-filling; Projections; Key for Plaster, Asphalt, etc.; Building in and Cutting and Pinning - Measurement of Facework: Measurement Generally; Brickwork Built Entirely of Facing Bricks; Plain Bands; Ornamental Bands; Margins; Fair Cutting; Protection Measurement of Blockwork - Worked Examples.

VI. MEASUREMENT OF CHIMNEY BREASTS AND STACKS, FIREPLACES, VENTS AND RUBBLE WALLING

Measurement of Chimney Breasts and Stacks : Brickwork in Breasts and Stacks; Flues - Fireplaces - Measurement of Vents - Measurement of Rubble Walling - Worked Examples.

VII. MEASUREMENT OF FLOORS

Hollow Floors - Plates - Floor Joists-Strutting - Floor Boarding - Solid Floors - Concrete Beds - Suspended Concrete Slabs Floor Finishings - Hollow-block and Contractor-designed Floors, etc. - Worked Examples.

VIII. MEASUREMENT OF ROOFS

Pitched Roofs: Construction; Coverings; Eaves and Rainwater Goods - Flat Roof Coverings: Asphalt; Bitumen-felt; Sheet Metal - Worked Examples.

IX. MEASUREMENT OF INTERNAL FINISHINGS

Ceiling Finishings - Wall Finishings; Schedules of Internal Finishings; Skirtings and Picture Rails - Floor Finishings - Painting and Decorations - Worked Example.

X. MEASUREMENT OF WINDOWS

Order of Measurement - Windows - Window Frames - Adjustment of Window Openings - Window Schedules - Worked Examples.

XI. MEASUREMENT OF DOORS

Order of Measurement-Doors-Door-Frames and Linings Adjustment of Door Openings - Worked Examples.

XII. MEASUREMENT OF STAIRCASES AND FITTINGS

Order of Measurement of Timber Staircases - Measurement of Component Parts of Staircases: Treads and Risers; Winders; 
Landings; Strings, Cappings ; Newels ; Handrails, Balusters ; Apronlinings; Spandril-shaped Panelled Partitions under Stairs; Sundries - Measurement of Fittings - Worked Example.

XIII. MEASUREMENT OF PLUMBING INSTALLATIONS

Order of Measurement - Drawings of Plumbing Installations Connection to Water Main - Pipework Generally - Pipe-fittings Water-storage Tanks - Holes for Pipes - Sanitary Appliances Builder's Work Connected with Plumbing Installations - Worked Example.

XIV. MEASUREMENT OF DRAINAGE WORK

Order of 'Taking-off' - Measurement of Drains - Drainage Accessories - Manholes - Associated Work - Worked Example.

XV. MEASUREMENT OF EXTERNAL WORKS

Roads, Drives and Paths - Grassed Areas - Planting of Trees and Shrubs - Fencing - Worked Example.

XVI. BILL PREPARATION PROCESSES

'Working-up' - 'Billing-direct' - Squaring Dimensions - Abstracting: Transfer of Dimensions; Subdivisions of Abstract; General Rules of Abstracting - Billing: Ruling of Bill of Quantities; Referencing of Items; Entering Items in the Bill; Units of Measurement; General Rules of Billing; Typical examples of Abstract and Bill; Preliminaries Bill; Bills of Reduction and Addenda Bills; Specialist Bills - 'Cut and Shuffle' - Use of Computers - Standard Phraseology-Operational Bills-Location and Annotated Bills Rationalisation of Measurement.

XVII. MEASUREMENT OF SMALL DWELLINGS

Purpose of Code - Variations in Measurement Procedure with use of Code.

Appendix I - Abbreviations 
xii

\section{Table of Figures}

Fig. No.

Subject

Page

\begin{tabular}{rlr}
\hline & Dimension paper & 10 \\
I & Girth of building & 20 \\
II & Girth of building (corners) & 21 \\
III & Girth of building (irregular building) & 22 \\
IV & Girth of building (irregular building) & 23 \\
V & Irregular area & 24 \\
VI & Trapezoid & 24 \\
VII & Segmental arch & 25 \\
VIII & Bellmouth & 25 \\
IX & Sloping site excavation & 26 \\
X & Excavation in cutting & 28 \\
XI & Lengths of rafters & 30 \\
XII & Lengths of hips and valleys & 31 \\
XIII & Intersection of internal and external walls & 34 \\
XIV & Measurement of excavated soil disposal & 35 \\
XV & Stepped foundation & 36 \\
XVI & Footings & 37 \\
XVII & Projections & 54 \\
XVIII & Stairs - treads and risers & 186 \\
XIX & Concrete protection to drain pipes & 211 \\
& Billing paper & 240 \\
XX & Cut and shuffle procedure & 254 \\
\hline
\end{tabular}




\section{Table of Examples}

\begin{tabular}{|c|c|c|c|}
\hline Chapter & Description & $\begin{array}{l}\text { Example } \\
\text { No. }\end{array}$ & $\begin{array}{l}\text { Drawing } \\
\quad \text { No. }\end{array}$ \\
\hline IV & Foundations to small building & I & 1 \\
\hline IV & Basement & II & 2 \\
\hline V & Brickwork, facework and blockwork & III & 3 \\
\hline V & Curved brick screen wall & IV & 4 \\
\hline VI & Chimney breast, stack and fireplace & V & 5 \\
\hline VI & Random rubble boundary wall & VI & - \\
\hline VII & Hollow ground floor & VII & 6 \\
\hline VII & Solid ground floor & VIII & 6 \\
\hline VII & Boarded upper floor & IX & 6 \\
\hline VII & Concrete upper floor & $\mathbf{X}$ & 6 \\
\hline VII & Stud partition & $\mathbf{X I}$ & 7 \\
\hline VIII & Pitched roof & XII & 8 \\
\hline VIII & Adjustment of roofwork for chimney stack & XIII & 8 \\
\hline VIII & Asphalt flat roof & XIV & 9 \\
\hline VIII & Lead flat roof & $\mathbf{X V}$ & 10 \\
\hline IX & Internal finishings & XVI & 11 \\
\hline $\mathrm{X}$ & Wood casement window & XVII & 12 \\
\hline $\mathbf{X}$ & Bullseye window & XVIII & 13 \\
\hline $\mathbf{X}$ & $\begin{array}{l}\text { Metal casement windows in stone } \\
\text { surround }\end{array}$ & XIX & 14 \\
\hline $\mathrm{XI}$ & Internal door & $\mathrm{XX}$ & 15 \\
\hline $\mathrm{XI}$ & External door & XXI & 16 \\
\hline XII & Timber staircase and shelving to larder & XXII & 17 \\
\hline XIII & Plumbing installation & XXIII & 18 \\
\hline XIV & Drainage work & XXIV & 19 \\
\hline XV & External works & XXV & 20 \\
\hline XVI & Abstracting & XXVI & - \\
\hline XVI & Billing & XXVII & - \\
\hline XVI & $\begin{array}{l}\text { Typical 'cut and shuffle' dimension } \\
\text { sheet }\end{array}$ & XXVIII & - \\
\hline
\end{tabular}

